\title{
Power and religion: \\ Geertz position of present-day Bali
}

\author{
Ni Wayan Radita Novi Puspitasari \\ Universitas Udayana, Ural Federal University, Russia \\ Email: dita_puspitasari88@hotmail.com
}

\begin{abstract}
This article analyzes the changes of religious - political power relations from the mid of 1950's to present-day Bali. Anthropologist Geertz stated that Balinese Hinduism is a "superstition", "rhetoric" and "state cult" that had been applied in the Negara as a theatre state. Within the conception of Hinduism by referring to the relation between the Divine God -Tri Murti and Tri Hita Karana, the Balinese society is believed in the relation between Gods, the people and its environment. Although in the post-colonial era, Balinese people are maintaining the power existence of the local kingdoms, mainly the system of warna. Through the accumulation of charisma, Geertz provided a concept that Negara was basically a state created by honor and ceremony. Thus, the democratic governmental system of Indonesia hardly reach the political arena within the Balinese society. As a result, through the self-awareness and the notion on equality, the Sudra could establish their role as an influential Balinese personage.
\end{abstract}

Keywords: the existence of power, religion, accumulation of charisma, negara, and local tradition

\begin{abstract}
Abstrak
Artikel ini menganalisis tentang perubahan hubungan kekuasaan antara agama dan politik dari tahun 1950-an sampai hariini di Bali. Geertz sebagai seorang antropolog menyatakan, bahwa Hindu-Bali merupakan takhayul, retoris dan Negara kultus yang telah diterapkan dalam konsep "Negara sebagai negara teater." Dalam konsepsi Hindu yang mengarah kepada hubungan antara Tuhan - Tri Murti dan Tri Hita Karana, masyarakat Bali mempercayai akan adanya hubungan erat antara Tuhan, masyarakat, dan lingkungannya. Walaupun pada masa sesudah kolonialisasi, masyarakat Bali masih memegang eksistensi dari kerajaan lokal, seperti sistem warna. Melalui akumulasi
\end{abstract}


kharisma, Geertz menyediakan sebuah konsep, bahwa Negara berdasarkan pada kehormatan dan adat. Maka dari itu, sistem pemerintahan demokrasi di Indonesia sulit sekali menyentuh aspek politik di dalam masyarakat Bali. Sebagai hasilnya, melalui kesadaran diri dan pandangan akan kesetaraan, golongan Sudra dapat membangun peran mereka sebagai tokoh-tokoh Bali yang berpengaruh.

Kata Kunci: kekuatan, agama, pengumpulan kharisma, negara, and tradisi lokal

\section{Introduction}

R ali nowadays is an inheritance of old Hindu-Pagan traditions B transformed into the largest tourist-targeted destination in Indonesia. The new look of Bali cannot be separated from the historical and anthropological aspects, which refers to the colonial period that the Dutch applied a project of "Balinisation of Bali" or Baliseering. The concept of "Balinisation of Bali" is an effort of the Dutch colonial government in the form of political culture that wanted to regain the authenticity and originality of Balinese culture (Howe, 2005: 18). It was not only a policy that applied to maintain the culture and preventing the entrance of Western culture to assimilate into Balinese customs, but it was an additional attempt to teach the society to become the 'real' identity of Balinese society. This linkage led Geertz to analyze the relationship between the domain of Balinese political power, religion and cultural symbols (adat). Thick description becomes one of his conceptions to investigate the historical process of its power-related connection to the society (Geertz, 1973: 5). It lies in the ethnographical objects of data that includes the multi-complex of conceptual structures of the word itself and culture need to be on literary and literacy metaphors whereupon culture is a public meaning (Hoffman, 2009:418).

In his book of Negara: The Theatre State in $19^{\text {th }}$ Century Bali, he described Negara as a classical form of commonwealth that supported by the religious-cultural aspect of Hinduism. The term of Negara as a theatre state is not based on the structure of bureaucratic regime, but it is more focused on the ceremonial and mass rituals which based on religious symbols, where he used the term as "power served pomp, not pomp power". He adds that, 
the term of Negara, came from the Sanskrit word and possess the meaning of town, palace, state, and capital (Geertz, 1980: 13).Local kingdoms were represented by the term of Negara that the area of Bali was divided into nine different kingdoms corresponding to the relation of Bali's regencies nowadays. Geertz also notified that the authoritative system consists of complex localized principalities that differ from the concept of "Oriental despotism" - it is the political regime of Asia in the pre-colonial era. In relation to Negara, religion has fundamental role in the relationship between the citizens and its rulers. Hindu priests (pedanda) played an influential part of the political dynamic in the scale of local state. They were the symbols of King's advisers on the matter of political, social, and cultural aspects according to the society. Between the King and his priest, it represented the strong relationship of power and religious countenance in Bali.

Aside from its puissance, religion strongly build the social order of "colors" (warna system), which refer to the term of caste in India. It detaches them to the collectiveness of "triwangsa" that belong to the upper castes, consist of Brahma, Ksatria, Waisya and to the excluded caste is the Sudra. From the colors differentiation, the standpoint of a person has been determined from the birth of his life, i.e. Sudra cannot become princes or priests. Yet, they still have the power in the term Geertz used as "supravillage" politics (Geertz, 1980: 27), that Sudra influenced the politic of the local kingdoms.

This paper delves into the changes of religious -political power relations from the mid of 1950's to present-day Bali. I will focus on the role of local elites and their priestess that maintained the traditions and symbols of Hinduism by following the dynamic of political movements in the local and national sphere. Rather than analyzing the contextual concept of negara as a theatre state, I pursuit to criticize the understanding of religion by Geertz as "superstition", "rhetoric" and "state cult" that had been applied in the state itself.

\section{Religion: The nucleus body of power and tradition}

The core of Balinese social life centered in the affiliation of religious-symbolic culture, that they practice in the everyday rituals, by giving offerings, praying to the gods, and celebrate Hindu festivals. Hindu, the oldest religion, had been described as a 
cult and superstition before Bali joined as a region of the Republic of Indonesia. It was strengthened by the statement of Geertz in his book of Negara: The Theatre State in $19^{\text {th }}$ Century Bali, that the theatre state was pervading by this superstition by applying it in one of the cruel funeral of King Gianyar which sacrificed three of his wives into their deaths (Geertz, 1980: 100). It is true that Balinese society applied such horrendous practices, but for the King's wives, it was a pride to show their loyalty and it would bring positive karma to their next life as a new reincarnation.

Geertz stating that Hindu religion was a superstition assimilated into the state cult - precisely misunderstood the conception of Hinduism. Although many of the outsiders believed that Hindu adherents worshipped idols, stones, and statues; it is the representatives of the nature that serve as the existence of Hindu Gods. To get a clear picture, look at this structure below:

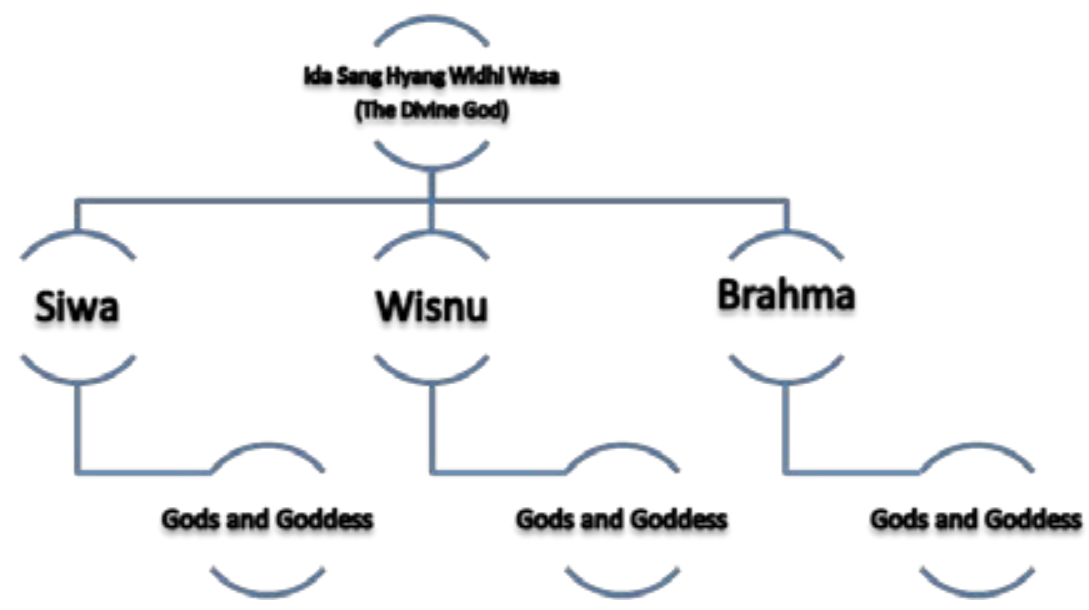

Table 1. Hierarchy of Hindu Gods

By looking at this table, the highest position is occupied by the Divine God of Ida Sang HyangWidhiWasa. Then, Tri Murti is a unity of three Gods by Siwa (the destroyer), Wisnu (the custodian) and Brahma (the creator), in which Siwa is the supreme God that the Balinese Hindu society adheres. It follows by other Gods and Goddess that are the representatives of the three unity of Tri Murti that have their own function as Geertz mentioned in the term of padmasana (lotus seat). Wisnu, Iswara, Mahadewa and Brahma 
seats in the four petals of lotus flower that symbolize the form of supernatural power of four wind directions (Howe, 2005: 11 and Geertz, 1980: 105) in the center of the lotus, Siwa is seated as the highest God among the others.

Balinese society is strongly believed in the relations between Gods, the individuals, and the environment. The relationship between the three aspects can be seen by the concept of Tri Hita Karana (three ways of peacefulness) that has the notion of (1) harmony to the God (Parhyangan); (2) harmony to people (Pawongan); and (3) harmony to the environment (Palemahan) (Access in http://www. thejakartapost.com/news/2010/03/15/nyepi-'tri-hita-karana'-anddevelopment.html (5 December 2015). The relationship of these three notions can be shown below:

Parhyangan

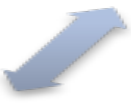

Palemahan

Pawongan

Table 2. The Concept of Tri Hita Karana

Through this concept, it is applicable to pray to the Gods and Bhuta Kala (malignant beings) by giving offerings for daily practices, such as banten saiban that placed in a four square of banana leafs and contain a small sum of rice and salt. The aim is to get salvation, serenity, and harmony for the individuals. By applying the concept of Tri Hita Karana, the Balinese society can reach the secular and supernatural peace. It also strengthened by the statement of John Stuart Mill that evidence of their experiences has taught them to build their own traditions and custom, (Mill, 2003: 123), in which it is based on symbols and practices of religious system of Balinese society. By using religion as a foundation of a state, Hinduism played a major role in the existence of negara that Geertz describe it as a 'theatre state' of the Balinese society. 


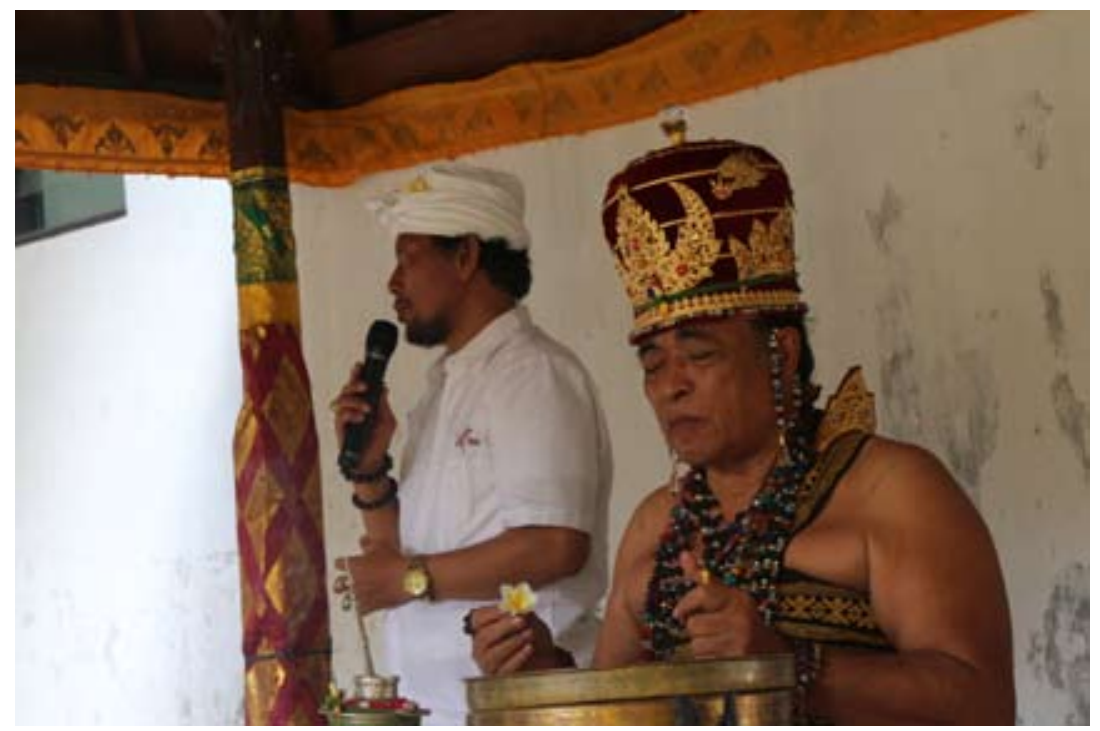

Photo 1. A brahmana priest officiates a temple ritual.

\section{Post-colonial Bali: The Power Existence of Local Kingdoms}

In a pre-colonial era, Bali was divided into several kingdoms and centered into royal houses called as puriorjero, depending on their status. In every region, the King and his kinship (dadia), belongs to the warna system of Ksatria, would live in an area that Geertz criticized as a 'theatre state'. It included the living house of Hindu priests (pedanda) in which it was called as geria. The relations between both of them, pedanda and dadia, had a reciprocal process in which it depends on the political and religious ground that can be stated in this quotation:

"On religious grounds the Brahmanas felt superior to the lords, a superiority they maintained through a monopoly of scriptural tradition and esoteric ritual knowledge. On political grounds the lords felt superior to the Brahmanas, a superiority they maintained through a monopoly of the instruments of rule". (Geertz, 1980: 37).

Geertz pointed out that in relationship between the King and his priest, there were two main distinctions of the formal types, i.e. the priest (pedanda) became an adviser for one royal house (puri) of Balinese elites that created a strong tie of teacher-disciple (siswasisia); and the lord's tribunal, in which they study the Indic law. By having the role of a priest as a teacher, they provided information of 
religious, political, cultural and social aspects of Bali Through this statement, there was disbelief and needs of belonging. They could not be disunited, because they related to the core of the religious and cultural symbols of Balinese society. Although the role of pedanda can be replaced by the Layman priest (pemangku) that came from the group of Sudra, but they could not replace the position of a pedanda as king's counselor and Hindu priests. As a consequence of the domination of both parties, it caused a further distinction between different warnas, especially between Brahmana-Ksatria to Sudra, in which the Sudra felt that they were discriminated by the upper caste.

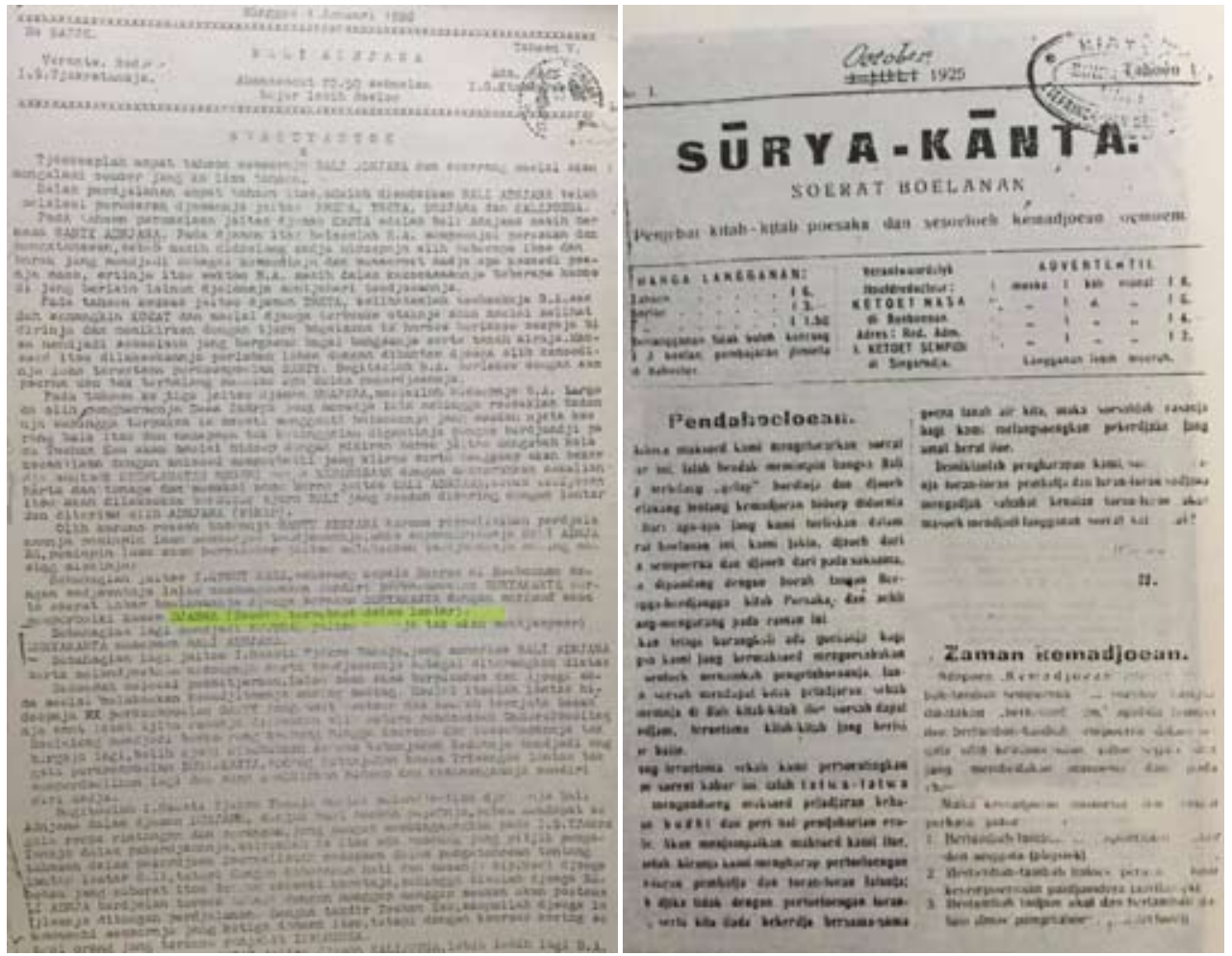

Photo 2. Newsletters Bali Adnjana and Surya Kanta.

Beginning in 1920s, the caste system had been debated by numerous Balinese scholars between the local magazines of Surya Kanta and Bali Adnjana. Surya Kanta and Bali Adnjana were local magazines, which was established in Singaraja in 1920s. These two magazines focused on the debates of the castes existence between 
Surya Kanta, led by K'tut Nasa, Nengah Metra and Nyoman Kajeng; and Bali Adnjana referred to the triwangsa and directed by I Gusti Putu Tjakratenaja. The local magazine of Surya Kanta was a group of Balinese intellectuals who studied in the Dutch schools in Java that most of them classified as Sudra (jaba). However, the Ducth banned the production of these magazines in 1929, because they were disquieted by the power of both parties that would harm the stability of the political situation in Bali (Putra, 2011: 151). The reason located by the power of local kingdoms had been decreasing during the Dutch colonial period. The Kings of Bali became the subject of the Dutch power, which conjointly suppressed the lowercaste, especially the Sudra, for providing goods, became as a labor of projects and local slaves considering the massive demand for Dutch company in Batavia (Jakarta nowadays). (Howe, 2005: 2324). Behind the other reasons, the local magazine of Surya Kanta wanted to erase the outdated traditions of caste that was not fitted for the modern time. Then, it was tapered after the rise of discrimination between triwangsa and educated jaba for the equal status of the lower-caste. Modernity, which was applied by the Western-educational system, became one of the essential factors that encouraged the emergence of the caste issues in Bali. However, this issue was suppressed by the Dutch immediately after it became a thread for the political stability in Bali.

After Indonesian Independence in 1945, Bali became one of the regions that belong to West Nusa Tenggara. The political structure of local kingdoms were changed into eight regencies that includes Badung, Bangli, Buleleng, Gianyar, Jembrana, Karangasem, Klungkung and Tabanan. It followed the position of the Kings (dadia) and their kinship by occupying themselves into the delegation of Balinese elites - whose positions were not changed in a local customs - as representatives in Indonesia. Through the declination of political power, local elites still have their symbolic figure - mainly the priests (pedanda) - to maintain their position as the rulers of Bali. In order to maintain the system of clientship, pedanda and dadia have mutual needs by saving each other political influence in the society. 


\section{Conclusion}

Since the existence of social order of warna system, the values of Hinduism as cultural customs became the core of Balinese society. By referring to Geertz statement that Balinese Hinduism is a "superstition", "rhetoric" and "state cult", the existence of Ida Sang Hyang Widhi Wasa as the Divine God and the applying concept of Tri Hita Karana are the validation that Balinese society can reach the secular and supernatural peace by using symbols and practices of Hindu religious system. It has been applied since Hindu reached the Balinese society to achieve the harmonious life between human to God, human to human, and human to their environment in which Geertz had failed to describe Hindu as a religion. On the one hand, this concept hopes to create balances and conformities through their life; on the other hand, the hierarchical system of warna strongly influence the social and political dynamic, in which the Brahmana and Ksatria played a major role to the leading future of Bali.

From the colonial period, Brahmana and Ksatria had an immense power through the social, political and cultural aspects that the Sudra could not be detached from their influence. Through the Dutch educational program and its modernity, the common people gained their power by making local magazine and newspaper, in which it was declined after the Dutch banned its publicity. Then, after the independence of Indonesia, they earned more power by the system of democracy and by the increasing amount of educated Balinese people. Although in the present days, the role of local elites has their strength to maintain the power of warna's system; through a long process, the Sudra can establish their own role as an influential Balinese personage.

\section{References}

Antari,LuhJumik.2015. “AjaranAstaBratasebagaiPedomanKepemimpinan Hindu". Accessed in http://www.kompasiana.com/ peradah/ajaran-asta-brata-sebagai-pedoman-kepemimpinanhindu 552dfe146ea83495138b45b0(6 December 2015).

Dharmada, Gung. "TigaCalon "Bertarung" di Pilwali Denpasar". Accessed inhttp://balipost.com/read/headline/2015/09/11/40847/ tiga-calon-bertarung-di-pilwali-denpasar.html $\quad$ (6 December 2015). 
Geertz, Clifford.1980. Negara: The Theatre State in 19 $9^{\text {th }}$ Century Bali. Princeton: Princeton University Press.

Geertz, Clifford.1973.Thick Description: Toward an Interpretive Theory of Culture.

Hoffman, Katherine E. 2009.“Culture as text: hazards and possibilities of Geertz's literary/literacy metaphor" in The Journal of North African Studies Vol. 14, Nos. 3/4, September/December 2009. London: Routledge.

Howe, Leo.2005. The Changing World of Bali: Religion, Society and Tourism. London: Routledge.

Mill, John Stuart.2003.On Liberty. London: Yale University Press.

Sewell Jr., William H. 1997. "Geertz, Cultural Systems, and History: From Synchrony to Transformation" in Representations, No. 59, Special Issue: The Fate of "Culture": Geertz and Beyond. University of California Press.

Parker, Lyn. 2003. From Subjects to Citizens: Balinese Villagers in the Indonesian Nation-State. Copenhagen: Nias Press.

Putra, I Nyoman Darma.2011. A Literary Mirror: Balinese Reflections on Modernity and Identity in the Twentieth Century. Leiden: KITLV Press.

Suwitha, I Putu Gede. "Elite Puri dalam Lanskap Politik Kontemporer di Bali" in Jurnal Kajian Bali, Volume 5, Nomor 1, April 2015. Denpasar: PusatKajian Bali, 2015. Accessed in http://webcache. googleusercontent.com/search?q=cache:nybOdEcH8AEJ:ojs. unud.ac.id/index.php/kajianbali/article/download/15728/10511 $+\& c d=3 \& h l=e n \& c t=c l n k \& g l=i d ~(6$ December 2015). 